Graphical abstract:

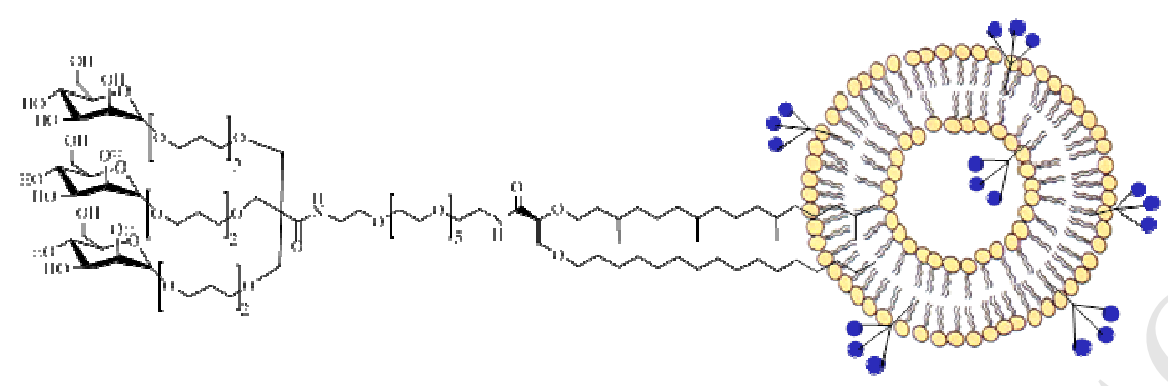




\title{
Synthesis of a Trimannosylated-Equipped Archaeal Diether Lipid for the
}

\section{Development of Novel Glycoliposomes}

\author{
Julie Barbeau, ${ }^{\text {a,d }}$ Loïc Lemiègre, ${ }^{\text {a,d }}$ Allan Quelen, ${ }^{\text {a,d }}$ Virginie Malard, ${ }^{\text {b }}$ Haifei Gao, ${ }^{\text {b }}$ \\ Cristine Gonçalves, ${ }^{\mathrm{b}}$ Mathieu Berchel, ${ }^{\mathrm{c}, \mathrm{d}}$ Paul-Alain Jaffrès, ${ }^{\mathrm{c}, \mathrm{d}}$ Chantal Pichon, ${ }^{\mathrm{b}}$ Patrick \\ Midoux, ${ }^{\text {b,* }}$ and Thierry Benvegnu ${ }^{a, d^{*}}$
}

(a) Ecole Nationale Supérieure de Chimie de Rennes, CNRS, UMR 6226, 11 Allée de Beaulieu, CS 50837, 35708 Rennes Cedex 7, France

(b) Centre de Biophysique Moléculaire, CNRS UPR 4301, Université d'Orléans, rue Charles Sadron, CS 80054, 45071 Orléans, France

(c) CEMCA, CNRS UMR 6521, SFR148 ScInBioS, Université de Brest, Brest, France

(d) Université de Bretagne Loire, France

\begin{abstract}
An archaeal diether lipid possessing a tri-antenna of $\alpha$-D-mannopyranoside linked via an oligoethylene spacer to a (2S)-2-(phytanyloxy)-3-(hexadecyloxy)propanoic acid backbone (TriMan-Diether) was designed and synthesized. This new mannosylated lipid inserted in liposomes would show both DC-targeting and adjuvant properties thanks to the TriMan structure and the diether tail part, respectively.
\end{abstract}

Keywords: Archaeal trimannosyl lipid, liposomes, dendritic cell binding, mannose receptor

\footnotetext{
* Corresponding authors: Ecole Nationale Supérieure de Chimie de Rennes, CNRS UMR 6226, 11 allée de Beaulieu, CS 50837, 35708 Rennes Cedex 7, France. E-mail address : thierry.benvegnu@ensc-rennes.fr; Centre de Biophysique Moléculaire, CNRS UPR 4301, Université d'Orléans, rue Charles Sadron CS 80054, 45071 Orléans, France. E-mail address: patrick.midoux@cnrs-orleans.fr
} 


\section{Introduction}

Ethers of lipids or archaeolipids naturally present in the membranes of Archaea are characterized by the presence of ether linkages between a glycerol and phytanyl aliphatic chains. ${ }^{1}$ They include those made with synthetically derived lipids that have the unique structural characteristics of natural lipids, for example: (1) regularly branched phytanyl chains linked through ether bonds to sn-2,3 carbons of glycerol; (2) monopolar archaeol (diether) lipids and/or bipolar tetraether lipids linked to two glycerol entities in an antiparallel manner (caldarchaeol) or in a parallel manner (isochaldarcheol); (3) neutral, negatively charged or zwitterionic unusual polar heads.

Glycolipid analogues with archaeal tetraether macrocycles bearing monovalent or trivalent lactose or mannose head groups at one or the two terminal ends were synthesized. ${ }^{2-4}$ Such glycolipids incorporated into liposomes allowed specific interactions with cell membrane receptors. Archaeal lipids exhibit adjuvant properties independent on Toll-like receptors activation which can be benefit to boost the immune response. ${ }^{5,3,6}$ Liposomes comprising these lipids, also called archaeosomes, possess an intrinsic adjuvant effect and mannosylated archaeal liposomes containing ovalbumin were able to induce anti-ovalbumin CD8+ $\mathrm{T}$ cell response in mice. ${ }^{6}$ The preparation of semi-synthetic compounds comprising ether lipids extracted from Archaea requires the establishment of archaea cultures, methods of extraction and isolation difficult to achieve at large scale. It is therefore necessary to synthetize ethertype compounds linked to a sugar group having the advantageous properties of lipids from Archaea.

Liposomes are very effective carriers to transport molecules of interest (drugs and nucleic acids) within cells. For better efficacy, liposomes must be recognized by the target cells, especially those used for vaccine proposals must be recognized and internalized by antigenpresenting cells notably dendritic cells (DCs) to deliver antigen. ${ }^{5}$ The targeting of DCs can be 
achieved by decoration of liposomes with ligands that are selectively recognized by surface receptors of DCs and permit their endocytosis. DCs express several sugar receptors called membrane lectins and most of them are involved in antigen capture and presentation. The Mannose receptor (MR) (CD206) recognizes mannose- and fucose-terminated glycans, Man9, 3-sulfo-LewisA, tri-GlcNAc, and palmitoyl-phosphatidylinositol dimannoside (PIMs) and induces clathrin-depend endocytosis. Other receptors including the DC-specific intercellular adhesion molecule-3-grabbing non-integrin (DC-SIGN), dectin-1, dectin-2 and Langerin bind

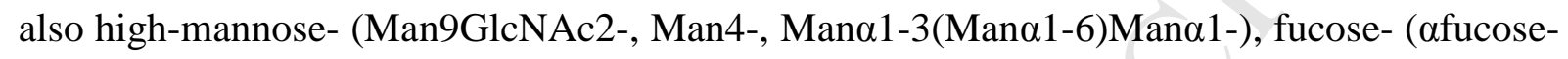
1-4GlcNAc-, Lacto- $N$-fucopentaose III-) and $N$-acetylglucosamine (GlcNAc2Man3-)terminated glycans as well as Lewis-type blood antigens (Leb or Lex trisaccharide), $\beta$ glucans. ${ }^{7}$ Carbohydrate-based targeting of the above mentioned receptors is an obvious manner to enhance specificity and uptake of liposomes. ${ }^{8}$ For this purpose, mono- or disaccharides are usually used. Indeed, the synthesis of high mannose structures and complex oligosaccharides in general that exhibit high affinity for membrane lectins is difficult, expensive and yields are weak. The binding affinity of monovalent carbohydrate ligands such as mannose typically is weak $\left(\mathrm{K} \approx 10^{-3} \mathrm{M}-10^{-4} \mathrm{M}\right)$. It can be increased by 1 or 2 orders of magnitude by coupling several monosaccharide units per protein, polymer or liposome. The multivalent decoration with monosaccharide units of low affinity increases the apparent affinity of the monosaccharide for its receptor. ${ }^{9}$ Natural oligosaccharides form antennary structures that allow higher affinity than monosaccharides. When compared, mono-, di-, and tetra-antennary mannosylated lipid derivatives revealed that liposomes containing multibranched mannosylated lipids displayed higher binding affinity for MR compared to monomannosylated analogues. ${ }^{10}$ Di-antennary mannosylated lipids were as efficient as the tetra-antennary lipids suggesting that the di-antennary structure was sufficient. 


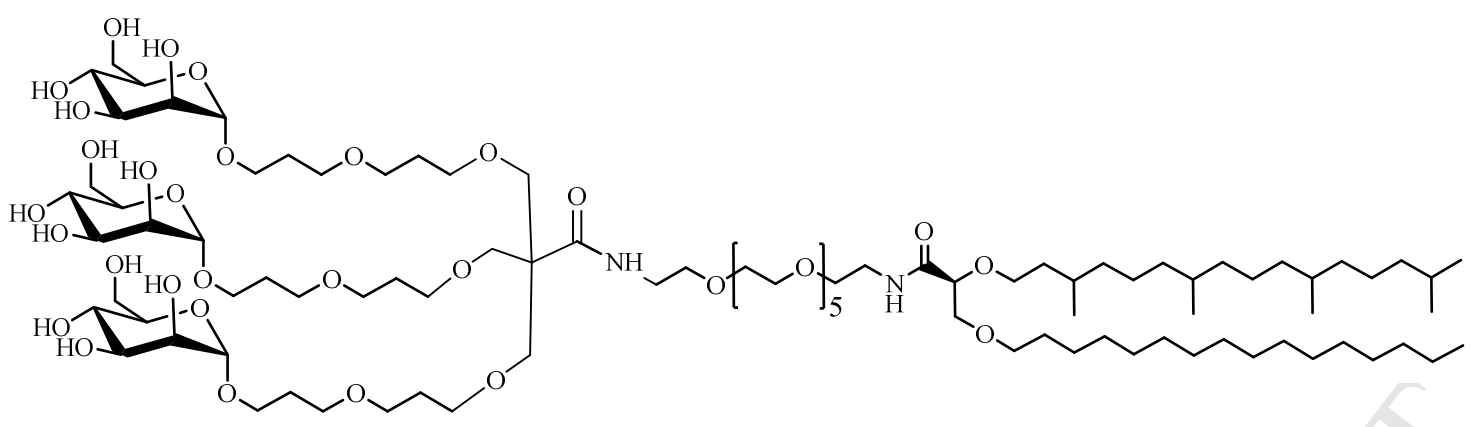

Figure 1. Structure of the trimannosylated diether lipid (TriMan-Diether) 1.

The present work relates for the first time to the synthesis of an archaeal-type diether lipid 1 (TriMan-Diether) derived from (2S)-2-(phytanyloxy)-3-(hexadecyloxy)propanoic acid linked via an oligo(ethylene glycol) spacer to a tri-antenna of alpha D-mannopyranoside. This lipid was designed to bring a sufficient flexibility to the head-group orientation with the objective of making the accessibility of mannose moieties optimal. The presence of both linear and branched chains represents an appropriate compromise between membrane fluidity and rigidity. A relatively short oligo(ethylene glycol) spacer-arm was selected to join the hydrophilic and the hydrophobic regions. This linker was considered to be sufficiently long to authorize a high degree of carbohydrate ligand exposure at the liposome surface.

The trimannosylated ligand is based on a pentaerythritol skeleton as an anchoring point for the construction of the tri-antenna structure. This tetraol was used for grafting three dipropylene glycol spacers followed by the fixation of the mannosyl units at their terminal ends. The length of the di-propylene glycol spacer is a key parameter for ensuring an optimized ligand-cell receptor binding since it will impact the distance (d) between the mannose residues. The preferred conformation of the tri-antenna structure for carbohydrate-cell recognition was found to require generally a distance (d) higher than $2 \AA,{ }^{11}$ this condition being met in the case of TriMan-Diether lipid $\mathbf{1 .}$ 


\section{Results and discussion}

\subsection{Synthesis of Trimannosyl diether lipid}

The strategic plan for the synthesis of TriMan-Diether $\mathbf{1}$ shown in Figure 1 involved a suitable synthesis of trimannosyl cluster $\mathbf{2}$ and its subsequent grafting onto amino PEGylated diether $\left(\mathrm{H}_{2} \mathrm{~N}-\mathrm{PEG}_{350}\right.$-Diether) 3 (Scheme 2). This convergent synthetic pathway is advantageous for the preparation of various triglycosylated lipids as it allows to module easily the length of the oligo(ethylene) spacer. Indeed the introduction of the tri-antenna moiety into the lipid backbone was performed in the final steps of the synthesis.

The construction of trimannosyl cluster 2 possessing three di-propylene glycol spacers was achieved in a seven-step procedure (Scheme 1) from commercially available pentaerythritol allyl ether 4 (technical grade, 70\%) after a purification step by silica gel chromatography. Quantitative benzylation of 4 was performed in DMF using 1.5 equiv of benzyl bromide in the presence of $\mathrm{NaH}$ (0.3 equiv). Hydroboration reactions with 9-BBN (9borabicyclo[3.3.1]nonane) followed by the in situ conversion to the corresponding triol under oxidative/basic conditions provided triol $6(83 \%)$. As expected, hydroboration of the allyl groups in $\mathbf{5}$ proceeded strictly regioselectively with the sterically demanding 9-BBN reagent. Triallylation of 6 with allyl bromide gave compound 7 in good yield (78\%). The same hydroboration/oxidation reaction using the $9-\mathrm{BBN} / \mathrm{H}_{2} \mathrm{O}_{2}, \mathrm{NaOH}$ conditions converted totally the triallylated derivative $\mathbf{7}$ into the corresponding triol $\mathbf{8}$. Subsequent mannosylation of $\mathbf{8}$ was carried out using 2,3,4,6-tetra- $O$-benzoyl- $\alpha$-mannosyl trichloroacetimidate $\mathbf{9}$ as the glycosyl donor in the presence of TMS triflate as the catalyst. As reported in the literature, ${ }^{12}$ the use of benzoylated trichloroacetimidate instead of the corresponding acetylated mannosyl donor completely avoided the orthoester formation. The mannosylation reaction was performed using various amounts of glycosyl donor (5 to 20 equiv in mol). The best results were obtained when 10 equiv of mannosyl trichloroacetimidate 9 was used (82\% yield) that 
corresponded to a little more than 3 equiv by hydroxyl group of compound 10. The exclusive formation of the $\alpha$-mannosides resulted from neighboring group participation of the $\mathrm{C}-2$ benzoyl donor functionality. Hydrogenolysis of the benzyloxy group furnished the corresponding benzoylated trimannosyl alcohol. At this stage, we envisaged the oxidation of primary alcohol into carboxylic acid 2 using a 2,2,6,6 tetramethylpiperidine $N$-oxide (TEMPO)-catalyzed oxidation reaction with $\mathrm{NaOCl} / \mathrm{NaClO}_{2}$ as the oxidizing agents. Fine tuning of the $\mathrm{pH}$ during the reaction gave a quantitative formation of carboxylic acid $\mathbf{2}$.
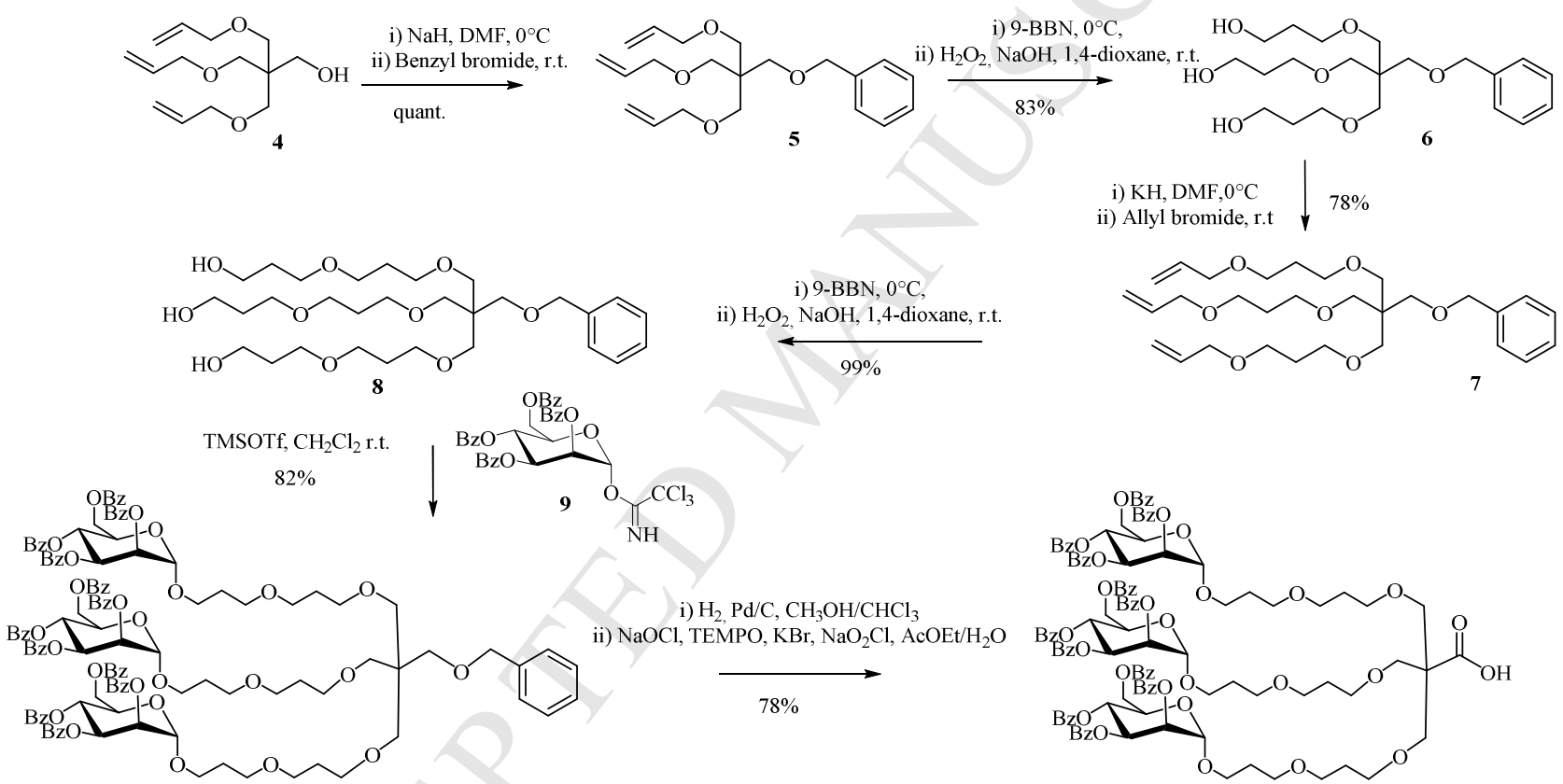

10

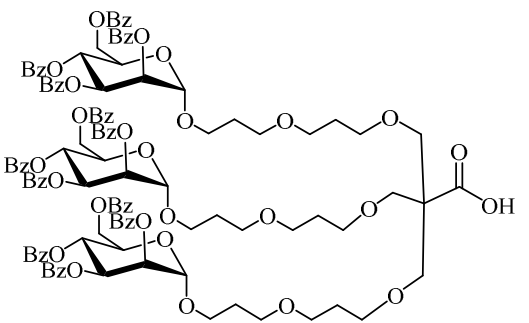

Trimannosyl cluster 2

Scheme 1. Synthesis of the trimannosyl cluster 2.

The preparation of $\mathrm{H}_{2} \mathrm{~N}-\mathrm{PEG}_{350}$-Diether $\mathbf{3}$ was performed through a coupling reaction between commercially available dissymmetrical $\mathrm{H}_{2} \mathrm{~N}-\mathrm{PEG}_{350}-\mathrm{N}_{3}$ chain $\mathbf{1 1}$ possessing an azido group that can be easily transformed into a primary amine by reduction, and (2S)-2(phytanyloxy)-3-(hexadecyloxy)propanoic acid 12 obtained using a synthetic route previously reported (Scheme 2). ${ }^{13}$ After experimentation, the uronium salt $O$-(benzotriazol-1-yl)1,1,3,3- 
tetramethyluronium tetrafluoroborate (TBTU) was identified as the best coupling reagent to provide the corresponding PEGylated diether $\mathbf{1 3}$ in a quite high yield (89\%). Finally the last step consisted in reducing the azide function by $\mathrm{PPh}_{3}$ in $\mathrm{THF} / \mathrm{H}_{2} \mathrm{O}$ to afford $\mathrm{H}_{2} \mathrm{~N}-\mathrm{PEG}_{350^{-}}$ Diether 3 in $80 \%$ yield.

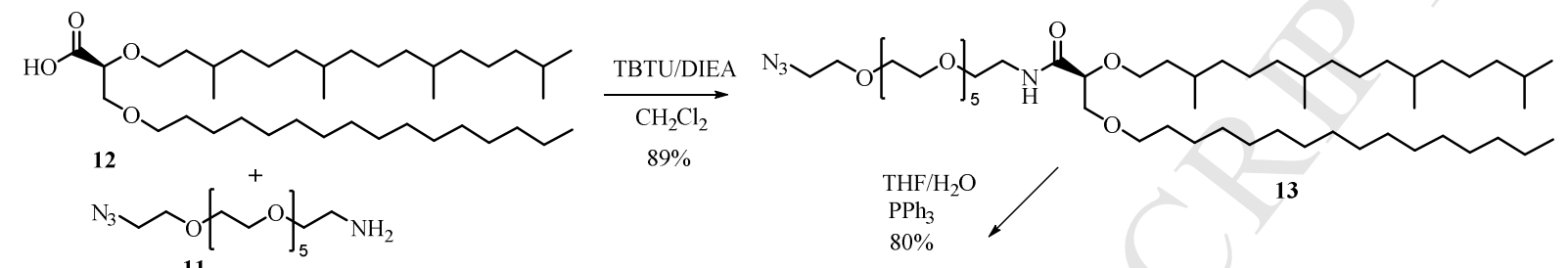<smiles>CCCCCCCCCCCCCCOCC(CCCC(C)C)CCCC(C)CCCC(C)CCCC(C)C</smiles>

$\mathrm{H}_{2} \mathrm{~N}-\mathrm{PEG}_{350}$ Diether 3

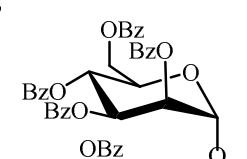

3
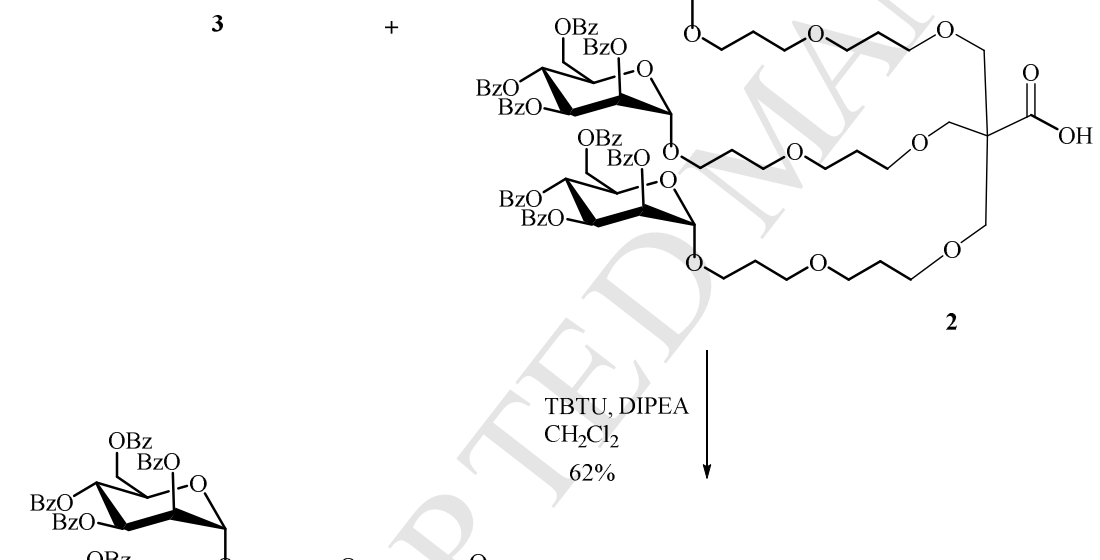

TBTU, DIPEA

$\mathrm{CH}_{2} \mathrm{Cl}_{2}$

$62 \%$
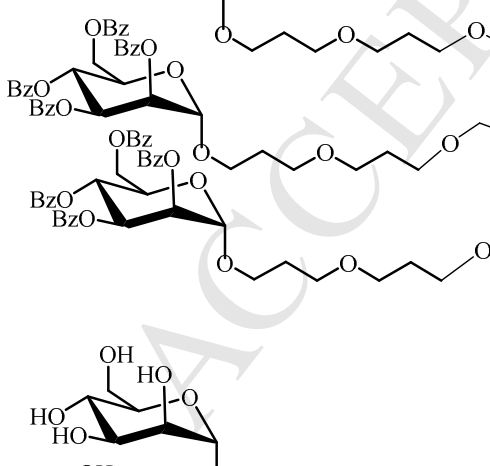

$\mathrm{MeONa}$

$\mathrm{MeOH} / \mathrm{CH}_{2} \mathrm{Cl}_{2}, 1 / 1$

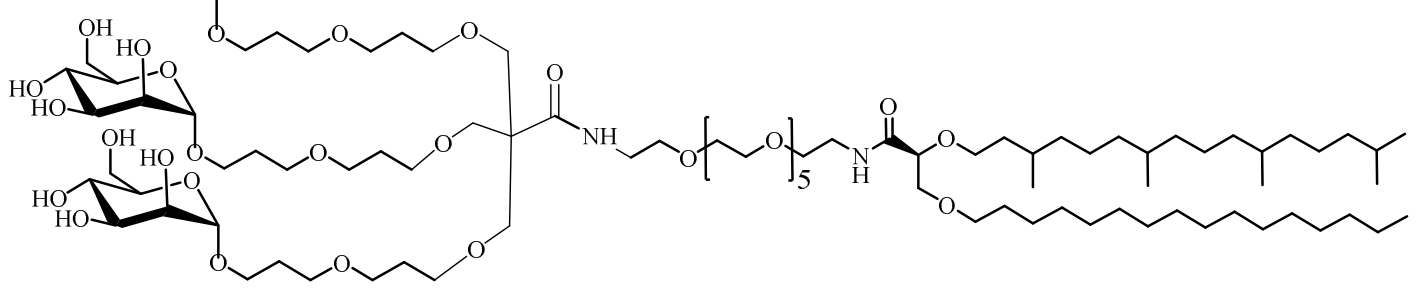

TriMan-Diether 1

Scheme 2. Synthesis of TriMan-Diether 1 
Having the amine $\mathbf{3}$ and carboxylic acid $\mathbf{2}$ in hand, the last crucial step involved the introduction of the trimannosylated ligand onto the lipid backbone (Scheme 2). The coupling reaction was accomplished by using the TBTU (1.5 equiv), DIEA ( 2.5 equiv) system and the reaction proceeded efficiently to afford the benzoylated trimannosylated diether $\mathbf{1 4}$ in $62 \%$ yield. Attempts based on other coupling conditions such as $N$-hydrosuccinimide (NHS), $N$-(3Dimethylamonipropyl)- $N$ '-ethylcarbodiimide hydrochloride (EDCI) decreased the yield to 30$45 \%$. The conventional deprotection of all hydroxyl groups by $\mathrm{MeONa}$ in $\mathrm{MeOH} / \mathrm{CH}_{2} \mathrm{Cl}_{2}$ (1/1) gave the totally unprotected TriMan-Diether $\mathbf{1}$ in $97 \%$ yield. This trimannosylated diether lipid was easily and fully characterized by NMR $\left({ }^{1} \mathrm{H}\right.$ and $\left.{ }^{13} \mathrm{C}\right)$ and high-resolution mass spectrometry.

\subsection{Binding of TriMan-liposomes on dendritic cells}

Then we tested whether TriMan-Diether 1 can trigger specific binding of liposomes on dendritic cells via the mannose receptor. DC2.4 cells are mouse dendritic cells that express the mannose receptor. ${ }^{14}$ TriMan-Diether $(5 \%)$ was incorporated in cationic liposomes made with three lipophosphoramidates with a polar head containing an imidazolium, histamine and fluorescein group in the percentage of $47.25 \%, 47.25 \%$ and $0.5 \%$, respectively (see experimental part). Those TriMan-liposomes exhibited a size of $213 \pm 16 \mathrm{~nm}$ and a positive charge of $58 \pm 5 \mathrm{mV}$.

When DC2.4 cells were incubated at $4^{\circ} \mathrm{C}$ with various concentrations of TriMan-liposomes, the fluorescence intensity of the cells (MFI) increased with the liposomes concentration showing the binding of those liposomes on DC2.4 cells (Figure 2). When the cells were preincubated with mannose before incubation with TriMan-liposomes in the presence of mannose, the MFI decreased. The inhibition was $70 \%$ in the presence of $500 \mathrm{mM}$ mannose in 
the presence of $64 \mu \mathrm{M}$ TriMan-liposomes indicating that the binding was mediated by the mannose receptor. The inhibition level varied with the mannose concentration (Figure 2 insert). The high concentration of free mannose required for a significant inhibition was indicative of a good affinity of the TriMan structure for the mannose receptor.

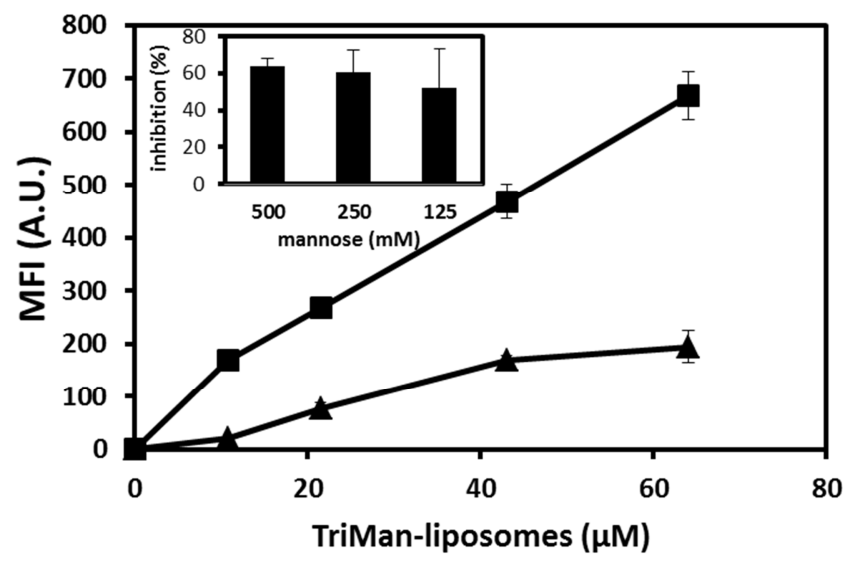

Figure 2. Binding of TriMan-liposomes onto DC2.4 cells and their inhibition by mannose. Cells in suspension were incubated for $2 \mathrm{~h}$ at $4{ }^{\circ} \mathrm{C}$ with fluorescein-labelled TriMan-liposomes $(\boldsymbol{\square})$ in the absence or $(\mathbf{\Delta})$ in the presence of mannose. The fluorescence intensity was measured by flow cytometry. MFI is the mean of the fluorescence intensity of 10,000 cells in arbitrary unit. Insert: percentage of inhibition of the binding of $43 \mu \mathrm{M}$ fluorescein-labelled TriMan-liposomes as a function of the mannose concentration.

\section{Conclusion}

We have developed a synthetic route for the preparation of a novel archaeal diether lipid functionalized with a mannose triantennary cluster (TriMan-Diether) designed as a multivalent ligand for the interaction with dendritic cells through their mannose-specific receptors. The convergent synthetic pathways were based on a peptidic-type coupling reaction between a PEGylated diether amine and a trimannosyl cluster possessing a carboxylic acid function. When $5 \%$ of this TriMan-Diether is inserted in liposomes it promotes a strong 
binding onto mouse dendritic cells mediated via the mannose receptor. This new mannosylated lipid that would show both DC-targeting and adjuvant properties thanks to the TriMan structure and the Diether tail part respectively can be benefit to boost the immune response.

\section{Experimental}

\subsection{General methods.}

Commercially available chemicals were used without further purification (except alcohol 4 which was purified by flash chromatography) and solvents were carefully dried and distilled prior to use. Unless otherwise noted, non-aqueous reactions were carried out under a nitrogen atmosphere. Analytical TLC was performed on Merck 60 F254 silica gel non-activated plates.

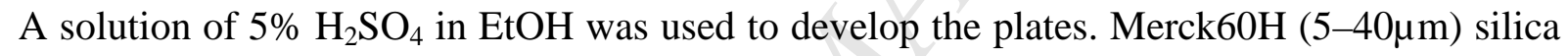
gel was used for flash chromatography. ${ }^{1} \mathrm{H}$ and ${ }^{13} \mathrm{C}$ NMR spectra were recorded at 400 and $100 \mathrm{MHz}$, respectively, on a Bruker Avance III. MS spectra were recorded on a Waters Micromass Q-TOF equipped with a Z-spray ion source or on a Shimadzu LCMS 2020 and optical rotation were recorded on a Perkin-Elmer 341 polarimeter.

\subsection{Synthesis of TriMan-Diether (1).}

\subsubsection{Triallyl-benzyl-pentaerythritol (5).}

To a suspension of $\mathrm{NaH}(2.6 \mathrm{~g}, 90 \mathrm{mmol})$ in anhydrous DMF $(100 \mathrm{~mL})$, alcohol 4 (7.70 g, $300 \mathrm{mmol}$ ) was added at $0^{\circ} \mathrm{C}$ and the reaction mixture was stirred during $2 \mathrm{~h}$ at the same temperature. Benzyl bromide $(7.7 \mathrm{~g}, 450 \mathrm{mmol})$ was added dropwise at $0^{\circ} \mathrm{C}$ and the reaction mixture was stirred during $17 \mathrm{~h}$ at room temperature. $\mathrm{MeOH}(6 \mathrm{~mL})$ was added dropwise at $0^{\circ} \mathrm{C}$, solvents were removed under reduced pressure and the crude material was dissolved in 
DCM and was washed twice with water and brine. The combined organic phases were dried $\left(\mathrm{MgSO}_{4}\right)$ and concentrated under reduced pressure. The residue was purified by flash chromatography on silica gel (Cyclohexane/EtOAc: 9:1) to yield 5 (10.45 g, quant.) as a colourless oil. ${ }^{1} \mathrm{H}$ NMR $\left(\mathrm{CDCl}_{3}, 400 \mathrm{MHz}\right) \delta(\mathrm{ppm}) 3.50\left(6 \mathrm{H}, \mathrm{s}, \mathrm{C}-\mathrm{CH}_{2}-\mathrm{O}\right), 3.56(2 \mathrm{H}, \mathrm{s}, \mathrm{C}-$ $\left.\mathrm{CH}_{2}-\mathrm{O}\right), 3.95\left(6 \mathrm{H}, \mathrm{dt}, J=5.3,1.5 \mathrm{~Hz}, \mathrm{CH}_{2}-\mathrm{CH}=\mathrm{CH}_{2}\right), 4.65\left(2 \mathrm{H}, \mathrm{s}, \mathrm{Ph}-\mathrm{CH}_{2}\right), 5.12(3 \mathrm{H}, \mathrm{dq}, J$ $\left.=10.4,1.7 \mathrm{~Hz}, \mathrm{CH}_{2}=\right), 5.24\left(3 \mathrm{H}, \mathrm{dq}, J=17.2,1.7 \mathrm{~Hz}, \mathrm{CH}_{2}=\right), 5.87(3 \mathrm{H}, \mathrm{m}, \mathrm{CH}=), 7.24-7.35$ $(7 \mathrm{H}, \mathrm{m}, \mathrm{Har})$. These analytical data are in total agreement with previously published data. ${ }^{3}$

\subsubsection{Tri(3-hydroxypropyl)-benzyl-pentaerythritol (6).}

To a solution of $5(10 \mathrm{~g}, 28.8 \mathrm{mmol})$ in dry dioxane $(50 \mathrm{~mL})$ was added at $0{ }^{\circ} \mathrm{C} 9$ borabicylco[3.3.1]nonane (0.5 M in THF; $519 \mathrm{~mL}, 0.259 \mathrm{~mol})$ and the reaction mixture was stirred at room temperature for $24 \mathrm{~h}$. An aqueous solution of sodium hydroxide $(577 \mathrm{~mL}, 3$ M) and a solution of $\mathrm{H}_{2} \mathrm{O}_{2}(115 \mathrm{~mL}, 30 \%)$ were added at $0{ }^{\circ} \mathrm{C}$ and the resulting mixture was stirred at room temperature for further $12 \mathrm{~h}$. The reaction mixture was extracted with EtOAc and the combined organic phases were dried $\left(\mathrm{MgSO}_{4}\right)$ and concentrated under reduced pressure. The residue was purified by flash chromatography on silica gel (EtOAc/Cyclohexane/MeOH: 10:5:1) to yield $6(9.57 \mathrm{~g}, 83 \%)$ as a colourless oil. ${ }^{1} \mathrm{H}$ NMR $\left(\mathrm{CDCl}_{3}, 400 \mathrm{MHz}\right) \delta(\mathrm{ppm}) 1.75\left(6 \mathrm{H}, \mathrm{p}, J=5.5,5.3 \mathrm{~Hz}, \mathrm{CH}_{2}-\mathrm{CH}_{2}-\mathrm{CH}_{2}\right), 3.28(3 \mathrm{H}$, broad s,

$\mathrm{OH}), 3.42\left(6 \mathrm{H}, \mathrm{s}, \mathrm{C}-\mathrm{CH}_{2}-\mathrm{O}\right), 3.44\left(2 \mathrm{H}, \mathrm{s}, \mathrm{C}-\mathrm{CH}_{2}-\mathrm{O}\right), 3.56\left(6 \mathrm{H}, \mathrm{t}, \mathrm{J}=5.5 \mathrm{~Hz}, \mathrm{O}-\mathrm{CH}_{2}-\mathrm{CH}_{2}\right)$, $3.70\left(6 \mathrm{H}, \mathrm{t}, J=5.3 \mathrm{~Hz}, \mathrm{CH}_{2}-\mathrm{OH}\right), 4.62\left(2 \mathrm{H}, \mathrm{s}, \mathrm{Ph}-\mathrm{CH}_{2}\right), 7.24-7.35(7 \mathrm{H}, \mathrm{m}, \mathrm{Har})$. These analytical data are in total agreement with previously published data. ${ }^{3}$

\subsubsection{Tri(3-allyloxypropyl)-benzyl-pentaerythritol (7).}

Triol 6 (7.8 g, $19.4 \mathrm{mmol})$ was dissolved in anhydrous DMF (100 mL) and this solution was added at $0^{\circ} \mathrm{C}$ dropwise to a suspension of $\mathrm{KH}(3.9 \mathrm{~g}, 97 \mathrm{mmol})$ in DMF $(100 \mathrm{~mL})$. The reaction mixture was stirred during $10 \mathrm{~min}$ before the slow addition of allyl bromide $(8.35$ 
$\mathrm{mL}, 97 \mathrm{mmol}$ ) at the same temperature. The reaction mixture was stirred during $24 \mathrm{~h}$ at room temperature and water $(100 \mathrm{~mL})$ was added carefully. The product was extracted three times with $\mathrm{Et}_{2} \mathrm{O}$ and the combined organic phases were washed with brine, dried $\left(\mathrm{MgSO}_{4}\right)$ and concentrated under reduced pressure. The residue was purified by flash chromatography on silica gel (Cyclohexana/EtOAc: $85: 15)$ to yield $7(8.63 \mathrm{~g}, 78 \%)$ as a colourless oil. $\mathrm{Rf}=0.15$ (Cyclohexane/EtOAC: 9:1); ${ }^{1} \mathrm{H}$ NMR $\left(\mathrm{CDCl}_{3}, 400 \mathrm{MHz}\right) \delta(\mathrm{ppm}) 1.81(6 \mathrm{H}, \mathrm{q}, J=6.4 \mathrm{~Hz}$, $\left.\mathrm{CH}_{2}-\mathrm{CH}_{2}-\mathrm{CH}_{2}\right), 3.40\left(6 \mathrm{H}, \mathrm{s}, \mathrm{C}-\mathrm{CH}_{2}\right), 3.44-3.50\left(14 \mathrm{H}, \mathrm{m}, \mathrm{CH}_{2}-\mathrm{O}\right), 3.95(6 \mathrm{H}$, ddd, $\mathrm{J}=5.7,1.5$, $\left.\mathrm{CH}_{2}-\mathrm{CH}=\right), 4.48\left(2 \mathrm{H}, \mathrm{s}, \mathrm{Ph}-\mathrm{CH}_{2}\right), 5.15\left(3 \mathrm{H}, \mathrm{ddd}, \mathrm{J}=10.3,3.3,1.5 \mathrm{~Hz}, \mathrm{CH}_{2}=\mathrm{CH}\right), 5.26(3 \mathrm{H}$, ddd, $\left.J=17.3,3.5,1.5 \mathrm{~Hz}, \mathrm{CH}_{2}=\mathrm{CH}\right), 5.90\left(3 \mathrm{H}, \mathrm{ddt}, J=10.3,6,8,5.7 \mathrm{~Hz}, C H=\mathrm{CH}_{2}\right), 7.24-$ $7.35(7 \mathrm{H}, \mathrm{m}, \mathrm{Har}) ;{ }^{13} \mathrm{C} \mathrm{NMR}\left(\mathrm{CDCl}_{3}, 100 \mathrm{MHz}\right) \delta(\mathrm{ppm}) 30.05,45.48,67.47,68.22,69.60$, $69.68,71.86,73.26,116.68,127.22,127.25,128.19,134.99,139.02$; MS (ESI) calculated for $\mathrm{C}_{30} \mathrm{H}_{48} \mathrm{O}_{7}[\mathrm{M}+\mathrm{Na}]^{+} 543.33$ found 543.35 .

\subsubsection{Tri(3-hydroxypropyloxypropyl)-benzyl-pentaerythritol (8).}

To a solution of $7(7.9 \mathrm{~g}, 15.0 \mathrm{mmol})$ in dry dioxane $(50 \mathrm{~mL})$ was added at $0{ }^{\circ} \mathrm{C} 9$ borabicylco[3.3.1]nonane (0.5 M in THF; $272 \mathrm{~mL}, 0.136 \mathrm{~mol})$ and the reaction mixture was stirred at room temperature for $24 \mathrm{~h}$. An aqueous solution of sodium hydroxide $(500 \mathrm{~mL}, 3$ M) and a solution of $\mathrm{H}_{2} \mathrm{O}_{2}(60 \mathrm{~mL}, 30 \%)$ were added at $0{ }^{\circ} \mathrm{C}$ and the resulting mixture was stirred at room temperature for further $12 \mathrm{~h}$. The reaction mixture was extracted with EtOAc and the combined organic phases were dried $\left(\mathrm{MgSO}_{4}\right)$ and concentrated under reduced pressure. The residue was purified by flash chromatography on silica gel (EtOAc/Cyclohexane/MeOH: 10:5:1) to yield $8(8.51 \mathrm{~g}, 99 \%)$ as a colourless oil. $\mathrm{Rf}=0.1$ (EtOAc/Cyclohexane/MeOH: 10:5:1); ${ }^{1} \mathrm{H} \mathrm{NMR}\left(\mathrm{CDCl}_{3}, 400 \mathrm{MHz}\right) \delta(\mathrm{ppm}) 1.79(12 \mathrm{H}, \mathrm{p}, J=$ $\left.5.7 \mathrm{~Hz}, \mathrm{CH}_{2}-\mathrm{CH}_{2}-\mathrm{CH}_{2}\right), 2.62\left(3 \mathrm{H}\right.$, broad s, OH), $3.42\left(6 \mathrm{H}, \mathrm{s}, \mathrm{C}-\mathrm{CH}_{2}\right), 3.49-3.43(14 \mathrm{H}, \mathrm{m}$, $\left.\mathrm{CH}_{2}-\mathrm{O}\right), 3.55\left(6 \mathrm{H}, \mathrm{t}, \mathrm{J}=5.7 \mathrm{~Hz}, \mathrm{CH}_{2}-\mathrm{O}\right), 3.73\left(6 \mathrm{H}, \mathrm{t}, J=5.4 \mathrm{~Hz}, \mathrm{CH}_{2}-\mathrm{OH}\right), 4.64(2 \mathrm{H}, \mathrm{s}, \mathrm{Ph}-$ 
$\left.\mathrm{CH}_{2}\right)$, 7.24-7.35 (7H, m, Har). ${ }^{13} \mathrm{C} \mathrm{NMR}(\mathrm{CDCl} 3,400 \mathrm{MHz}) \delta(\mathrm{ppm}) 29.96,32.01,45.47$, $61.93,68.09,68.29,69.52,69.72,70.10,73.26,127.24,127.28,128.20,138.96$.

\subsubsection{TriMan- $\mathrm{CH}_{2} \mathrm{OBn}(10)$.}

To a mixture of the mannosyl donnor $9(10 \mathrm{~g}, 13.4 \mathrm{mmol})$ and triol $8(1.03 \mathrm{~g}, 1.79 \mathrm{mmol})$ in dry dichloromethane $(5 \mathrm{~mL})$ was added a solution of trimethylsilyl trifluoromethane sulfonate $(640 \mu \mathrm{L}, 0.179 \mathrm{mmol} ; 5 \%$ in DCM) and the reaction mixture was stirred at room temperature for $12 \mathrm{~h} . \mathrm{NaHCO}_{3}(2 \mathrm{~g})$ was added and the reaction mixture was concentrated under reduced pressure. The residue was purified by flash chromatography on silica gel (Cyclohexane/EtOAc: 6:4) to yield $\mathbf{1 0}(3.44 \mathrm{~g}, 82 \%)$ as a yellowish solid. $\mathrm{Rf}=0.3$ (Cyclohexane/EtOAc: 6:4); m.p. $=61^{\circ} \mathrm{C} ;[\alpha]^{20}{ }_{\mathrm{D}}=-32.4\left(\mathrm{c} 0.9 \mathrm{CHCl}_{3}\right) ;{ }^{1} \mathrm{H} \mathrm{NMR}\left(\mathrm{CDCl}_{3}, 400\right.$ $\mathrm{MHz}) \delta(\mathrm{ppm}) 1.77-1.84\left(6 \mathrm{H}, \mathrm{m}, J=6.4 \mathrm{~Hz}, \mathrm{CH}_{2}-\mathrm{CH}_{2}-\mathrm{CH}_{2}\right), 1.91-2.00\left(6 \mathrm{H}, \mathrm{m}, \mathrm{CH}_{2}-\mathrm{CH}_{2^{-}}\right.$ $\left.\mathrm{CH}_{2}\right), 3.41-3.57\left(26 \mathrm{H}, \mathrm{m}, \mathrm{CH}_{2}-\mathrm{O}\right), 3.57-3.68\left(3 \mathrm{H}, \mathrm{m}, \mathrm{CH}_{2}-\mathrm{O}\right), 3.90-3.96\left(3 \mathrm{H}, \mathrm{m}, \mathrm{CH}_{2}-\mathrm{O}\right)$, 4.40-4.50 (3H, m, H5), 4.46-4.50 (5H, m, Ph- $\left.\mathrm{CH}_{2}, \mathrm{H} 6 \mathrm{~b}\right), 5.08$ (3H, d, J = 2.0 Hz, H1), 5.70 $(3 \mathrm{H}, \mathrm{dd}, J=3.2,1.8 \mathrm{~Hz}, \mathrm{H} 2), 5.91(3 \mathrm{H}, \mathrm{dd}, J=10.1,3.3 \mathrm{~Hz}, \mathrm{H} 3), 6.11(3 \mathrm{H}, \mathrm{t}, J=10.1 \mathrm{~Hz}$, $\mathrm{H} 4), 7.24-8.11$ (65H, m, Har); ${ }^{13} \mathrm{C} \mathrm{NMR}\left(\mathrm{CDCl}_{3}, 100 \mathrm{MHz}\right) \delta(\mathrm{ppm}) 29.73,30.04,45.46$, $62.84,65.58,66.94,67.30,68.22,68.31,68.77,69.71,70.15,70.53,73.24,97.62,127.20$, $127.23,128.18,128.28,128.42,128.55,128.98,129.09,129.35,129.72,129.77,129.83$, $129.87,133.02,133.13,133.40,139.05,165.39,165.45,165.48,166.13$.

\subsubsection{TriMan-COOH (2).}

Debenzylation. A mixture of $\mathbf{1 0}(3.44 \mathrm{~g}, 1.49 \mathrm{mmol})$ and palladium on activated carbon (340 $\mathrm{mg}, 10 \% \mathrm{w} / \mathrm{w})$ in $\mathrm{CH}_{2} \mathrm{Cl}_{2} / \mathrm{MeOH}(30 \mathrm{~mL}, 4: 1)$ was stirred overnight at room temperature under hydrogen atmosphere. The reaction mixture was filtered on Celite $®$ and the filtrate was concentrated under reduced pressure. The residue was purified by flash chromatography on silica gel (Cyclohexane/EtOAc: 6:4) to yield the corresponding alcohol (2.61 g, 79\%) as a 
white solid. $\mathrm{Rf}=0.4\left(\right.$ Cyclohexane/EtOAc/MeOH: 6:3:1); m.p. $=69^{\circ} \mathrm{C} ;[\alpha]^{20}{ }_{\mathrm{D}}=-33.6(\mathrm{c} 2.2$ $\left.\mathrm{CHCl}_{3}\right) ;{ }^{1} \mathrm{H} \mathrm{NMR}\left(\mathrm{CDCl}_{3}, 400 \mathrm{MHz}\right) \delta(\mathrm{ppm}) 1.81\left(6 \mathrm{H}, \mathrm{p}, J=6.4 \mathrm{~Hz}, \mathrm{CH}_{2}-\mathrm{CH}_{2}-\mathrm{CH}_{2}\right), 1.93$ $\left(6 \mathrm{H}, \mathrm{p}, J=6.4 \mathrm{~Hz}, \mathrm{CH}_{2}-\mathrm{CH}_{2}-\mathrm{CH}_{2}\right), 3.04(1 \mathrm{H}, \mathrm{t}, J=6.1 \mathrm{~Hz}, \mathrm{OH}), 3.43\left(6 \mathrm{H}, \mathrm{s}, \mathrm{C}-\mathrm{CH}_{2}\right), 3.47$ $\left(6 \mathrm{H}, \mathrm{t}, J=6.3 \mathrm{~Hz}, \mathrm{CH}_{2}-\mathrm{O}\right), 3.50\left(6 \mathrm{H}, \mathrm{t}, \mathrm{J}=6.5 \mathrm{~Hz}, \mathrm{CH}_{2}-\mathrm{O}\right), 3.55\left(6 \mathrm{H}, \mathrm{m}, \mathrm{CH}_{2}-\mathrm{O}\right), 3.68(5 \mathrm{H}$, m, $\left.\mathrm{CH}_{2}-\mathrm{O}\right), 3.91\left(3 \mathrm{H}, \mathrm{dt}, J=9.7,6.4 \mathrm{~Hz}, \mathrm{CH}_{2}-\mathrm{O}\right), 4.39-4.43(3 \mathrm{H}, \mathrm{m}, \mathrm{H} 5), 4.47(3 \mathrm{H}, \mathrm{dd}, J=$ 12.0, 4.2 Hz, H6a), 4.68 (3H, dd, $J=12.0,2.4 \mathrm{~Hz}, \mathrm{H} 6 \mathrm{~b}), 5.07$ (3H, d, $J=1.7 \mathrm{~Hz}, \mathrm{H} 1), 5.69$ $(3 \mathrm{H}, \mathrm{dd}, J=3.3,1.7 \mathrm{~Hz}, \mathrm{H} 2), 5.91(3 \mathrm{H}, \mathrm{dd}, J=10.1,3.3 \mathrm{~Hz}, \mathrm{H} 3), 6.11(3 \mathrm{H}, \mathrm{t}, J=10.1 \mathrm{~Hz}$, H4), 7.23-7.41 (20H, m, Har), 7.41-7.58 (20H, m, Har), 7.82-8.08 (20H, m, Har); ${ }^{13} \mathrm{C}$ NMR (CDCl3, $100 \mathrm{MHz}) \delta$ (ppm) 29.69 (C8), 29.95 (C5), 44.81 (C3a), 62.84 (C6’), 65.56 (C9), $66.05,66.94,67.37,68.11,68.67,68.78,70.14,70.53,71.46,97.61,128.28,128.42,128.56$, $128.99,129.09,129.35,129.72,129.78,129.83,129.87,133.03,133.14,133.41,165.39$, 165.44, 165.49, 166.13; HRMS (ESI) calculated for $\mathrm{C}_{125} \mathrm{H}_{126} \mathrm{O}_{37}[\mathrm{M}+\mathrm{Na}]^{+} 2241.78702$, found

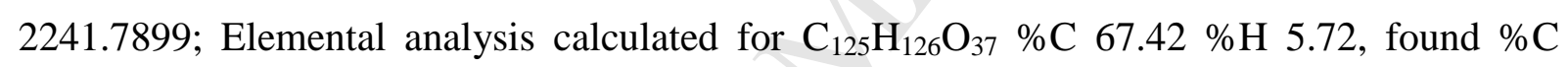
$67.53, \% \mathrm{H} 5.62$.

Oxidation. Previous alcohol (614 mg, $0.275 \mathrm{mmol})$ was dissolved in EtOAc $(10 \mathrm{~mL})$. Aqueous solutions of $\mathrm{KBr}(56 \mu \mathrm{L}, 0.5 \mathrm{M}, 0.028 \mathrm{mmol})$ and TEMPO (15 mg, $0.096 \mathrm{mmol})$ were added, followed by the addition of $\mathrm{NaOCl}(1.2 \mathrm{~mL}, 0.84 \mathrm{mmol})$ at $0^{\circ} \mathrm{C}$. After $3 \mathrm{~h}$ at room temperature, the reaction mixture was acidified with $5 \% \mathrm{HCl}$ until $\mathrm{pH} 3$ before the addition of $\mathrm{NaO}_{2} \mathrm{Cl}(560 \mu \mathrm{L}, 1.68 \mathrm{mmol})$. The reaction mixture was stirred overnight at room temperature and then was extracted with EtOAc. The combined organic phases were dried $\left(\mathrm{MgSO}_{4}\right)$ and concentrated under reduced pressure to give the carboxylic acid $2(614 \mathrm{mg}, 99 \%)$. Rf $=0.2$ $\left(\right.$ Cyclohexane/EtOAc/MeOH: 6:3:1); m.p. $=73^{\circ} \mathrm{C} ;[\alpha]^{20}{ }_{\mathrm{D}}=-27.7\left(\mathrm{c} 2.4 \mathrm{CHCl}_{3}\right) ;{ }^{1} \mathrm{H}$ NMR $\left(\mathrm{CDCl}_{3}, 400 \mathrm{MHz}\right) \delta(\mathrm{ppm}) 1.83\left(6 \mathrm{H}, \mathrm{p}, J=6.3 \mathrm{~Hz}, \mathrm{CH}_{2}-\mathrm{CH}_{2}-\mathrm{CH}_{2}\right), 1.96(6 \mathrm{H}, \mathrm{p}, J=6.2 \mathrm{~Hz}$, $\left.\mathrm{CH}_{2}-\mathrm{CH}_{2}-\mathrm{CH}_{2}\right), 3.51\left(6 \mathrm{H}, \mathrm{t}, \mathrm{J}=6.3 \mathrm{~Hz}, \mathrm{CH}_{2}-\mathrm{O}\right), 3.53\left(6 \mathrm{H}, \mathrm{t}, \mathrm{J}=6.1 \mathrm{~Hz}, \mathrm{CH}_{2}-\mathrm{O}\right), 3.56(6 \mathrm{H}$, m, $\left.\mathrm{CH}_{2}-\mathrm{O}\right), 3.64\left(6 \mathrm{H}, \mathrm{s}, \mathrm{C}-\mathrm{CH}_{2}\right), 3.66\left(3 \mathrm{H}, \mathrm{td}, J=9.7,6.4 \mathrm{~Hz}, \mathrm{CH}_{2}-\mathrm{O}\right), 3.94(3 \mathrm{H}, \mathrm{td}, J=9.7$, 
$\left.6.4 \mathrm{~Hz}, \mathrm{CH}_{2}-\mathrm{O}\right), 4.47-4.41(3 \mathrm{H}, \mathrm{m}, \mathrm{H} 5), 4.49$ (3H. dd. $\left.J=12.0 .4 .2 \mathrm{~Hz}, \mathrm{H} 6 \mathrm{~b}\right), 4.71(3 \mathrm{H}, \mathrm{dd}, J$ = 12.0, 2.4 Hz. H6a), $5.10(3 \mathrm{H}, \mathrm{d}, J=1.7 \mathrm{~Hz}, \mathrm{H} 1), 5.70(3 \mathrm{H}, \mathrm{dd}, J=3.3,1.7 \mathrm{~Hz}, \mathrm{H} 2), 5.92$ (3H, dd, $J=10.1,3.3 \mathrm{~Hz}, \mathrm{H} 3), 6.13(3 \mathrm{H}, \mathrm{t}, J=10.0 \mathrm{~Hz}, \mathrm{H} 4), 7.24-7.59$ (36H, m, Har), 7.82$8.11(24 \mathrm{H}, \mathrm{m}, \mathrm{Har}) ;{ }^{13} \mathrm{C} \mathrm{NMR}\left(\mathrm{CDCl}_{3}, 100 \mathrm{MHz}\right) \delta(\mathrm{ppm}) 29.60,29.77,52.86,60.34,62.79$, $65.46,66.85,67.31,67.87,68.59,68.73,69.07,70.13,70.49,97.55,128.24,128.38,128.52$ $128.92,129.00,129.27,129.68,129.73,129.78,133.02,133.12,133.37,133.39,165.39$, 165.42, 165.50, 166.15, 173.45; Elemental analysis calculated for $\mathrm{C}_{125} \mathrm{H}_{124} \mathrm{O}_{38} \% \mathrm{C} 67.20 \% \mathrm{H}$ 5.59, found $\% \mathrm{C} 67.15, \% \mathrm{H} 5.70$.

\subsection{7. $\mathrm{N}_{3}$-PEG 350 -diether (13).}

DIEA (188 $\mu \mathrm{L}, 1.08 \mathrm{mmol})$ was added to a mixture of $12(508 \mathrm{mg}, 0.831 \mathrm{mmol})$ and TBTU (347 mg, $1.08 \mathrm{mmol}$ ) in dry $\mathrm{CH}_{2} \mathrm{Cl}_{2}(15 \mathrm{~mL})$ under nitrogen atmosphere. After $20 \mathrm{~min}$ at room temperature, a solution of $\mathrm{N}_{3}-\mathrm{PEG}_{350}-\mathrm{NH}_{2}(291 \mathrm{mg}, 0.831 \mathrm{mmol})$ in dry $\mathrm{CH}_{2} \mathrm{Cl}_{2}(5 \mathrm{~mL})$ was added and the reaction mixture was stirred for $12 \mathrm{~h}$. An aqueous solution of $\mathrm{HCl} 1 \mathrm{~N}$ was added and the organic phase was washed with water. The combined organic phases were dried $\left(\mathrm{MgSO}_{4}\right)$ and concentrated under reduced pressure. Flash chromatography on silica gel (DCM/MeOH: 98:2) yielded $13(700 \mathrm{mg}, 89 \%)$ as a yellow oil; $\mathrm{Rf}=0.36(\mathrm{DCM} / \mathrm{MeOH}$ : 95:5); ${ }^{1} \mathrm{H}$ NMR $\left(\mathrm{CDCl}_{3}, 400 \mathrm{MHz}\right) \delta(\mathrm{ppm})$ 0.83-0.87 (m, 18H, $\left.6 \mathrm{CH}_{3}\right), 1.04-1.78$ (m, 52H, $\left.24 \mathrm{CH}_{2}, 4 \mathrm{CH}\right), 3.37-3.40\left(\mathrm{~m}, 2 \mathrm{H}, \mathrm{CH}_{2}-\mathrm{N}_{3}\right), 3.41-3.50\left(\mathrm{~m}, 4 \mathrm{H}, \mathrm{CH}_{2}-\mathrm{N}, \mathrm{CH}_{2}-\mathrm{O}\right), 3.53-3.57$ (m, 4H, $\left.\mathrm{CH}_{2}-\mathrm{O}\right), 3.58-3.69\left(\mathrm{~m}, 23 \mathrm{H}, \mathrm{CH}_{2}-\mathrm{O}\right), 3.75-3.78$ (m, $\left.1 \mathrm{H}, \mathrm{CH}_{2}-\mathrm{O}\right), 3.88-3.90$ (dd, $\mathrm{J}=$ 2.51, $5.92 \mathrm{~Hz}, 1 \mathrm{H}, \mathrm{CH}-\mathrm{O}), 7.02-7.05(\mathrm{~m}, 1 \mathrm{H}, \mathrm{NH}) ;{ }^{13} \mathrm{C} \mathrm{NMR}\left(\mathrm{CDCl}_{3}, 100 \mathrm{MHz}\right) \delta(\mathrm{ppm})$ $14.10,19.58,19.65,19.72,22.60,22.69,22.66,24.36,24.47,24.78,26.03,27.94,29.84$, $32.76,32.78,29.34,29.46,29.52,29.63,29.68,31.89,37.26,37.36,37.39,37.45,37.50$, 39.32, 38.67, 50.63, 69.72, 69.83, 70.3-70.7, 71.47, 71.68, 80.48, 170.57; MS (ESI) calculated for $\mathrm{C}_{53} \mathrm{H}_{106} \mathrm{~N}_{4} \mathrm{O}_{9}[\mathrm{M}+\mathrm{Na}]^{+}$965.79, found 965.80 . 


\section{ACCEPTED MANUSCRIPT}

\subsection{8. $\mathrm{NH}_{2}-\mathrm{PEG}_{350}$-diether (3).}

Triphenylphosphine ( $88 \mathrm{mg}, 0.337 \mathrm{mmol}$ ) was added portionwise to a stirred solution of $\mathbf{1 3}$ (212 mg, $0.224 \mathrm{mmol})$ in $\mathrm{THF} / \mathrm{H}_{2} \mathrm{O}(25 \mathrm{~mL}, 1: 1)$. After $18 \mathrm{~h}$ at room temperature, the solvent was removed under reduced pressure. Flash chromatography on silica gel (DCM/MeOH: 95:5) yielded amine $3(164 \mathrm{mg}, 80 \%)$ as a yellowish oil; $\mathrm{Rf}=0.54(\mathrm{DCM} / \mathrm{MeOH}: 9: 1) ;{ }^{1} \mathrm{H}$ NMR $\left(\mathrm{CDCl}_{3}, 400 \mathrm{MHz}\right) \delta(\mathrm{ppm})$ 0.82-0.88 (m, 18H, $\left.6 \mathrm{CH}_{3}\right), 0.99-1.69\left(\mathrm{~m}, 52 \mathrm{H}, 24 \mathrm{CH}_{2}, 4\right.$ $\mathrm{CH}), 3.16-3.18\left(\mathrm{~m}, 2 \mathrm{H}, \mathrm{CH}_{2}-\mathrm{NH}_{2}\right), 3.39-3.49\left(\mathrm{~m}, 4 \mathrm{H}, \mathrm{CH}_{2}-\mathrm{NH}, \mathrm{CH}_{2}-\mathrm{O}\right), 3.54-3.57(\mathrm{~m}, 4 \mathrm{H}$, $\left.\mathrm{CH}_{2} \mathrm{-O}\right), 3.59-3.70\left(\mathrm{~m}, 18 \mathrm{H}, \mathrm{CH}_{2}-\mathrm{O}\right), 3.72-3.75\left(\mathrm{~m}, 3 \mathrm{H}, \mathrm{CH}_{2}-\mathrm{O}\right), 3.76-3.77\left(\mathrm{~m}, 1 \mathrm{H}, \mathrm{CH}_{2}-\mathrm{O}\right)$, 3.87-3.90 (m, 3H, $\left.\mathrm{CH}_{2}-\mathrm{O}, \mathrm{CH}-\mathrm{O}\right), 7.04-7.06$ (m, $\left.1 \mathrm{H}, \mathrm{NHCO}\right) ;{ }^{13} \mathrm{C} \mathrm{NMR}\left(\mathrm{CDCl}_{3}, 100 \mathrm{MHz}\right) \delta$ (ppm) 14.10, 19.58, 19.65, 19.72, 22.61, 22.71, 22.66, 24.34, 24.45, 24.76, 26.00, 27.95, $29.77,29.85,32.79,29.32,29.45,29.54,20.61,29.66,31.88,37.23,37.34,37.37,37.43$, 39.31, 38.70, 40.45, 66.89, 69.72-70.53, 71.45, 71.70, 80.47, 170.63; MS (ESI) calculated for $\mathrm{C}_{53} \mathrm{H}_{108} \mathrm{~N}_{2} \mathrm{O}_{9}[\mathrm{M}+\mathrm{H}]^{+}$917.81, found 917.80.

\subsubsection{Perbenzoyl-TriMan-PEG 350 -diether (14).}

DIEA $(112 \mu \mathrm{L}, 0.643 \mathrm{mmol})$ was added to a mixture of $2(575 \mathrm{mg}, 0.257 \mathrm{mmol})$ and TBTU (124 mg, $0.386 \mathrm{mmol}$ ) in dry $\mathrm{CH}_{2} \mathrm{Cl}_{2}(70 \mathrm{~mL})$ under nitrogen atmosphere. After $20 \mathrm{~min}$ at room temperature, a solution of diether- $\mathrm{PEG}_{350}-\mathrm{NH}_{2} \mathbf{3}(335 \mathrm{mg}, 0.365 \mathrm{mmol})$ in dry $\mathrm{CH}_{2} \mathrm{Cl}_{2}$ $(50 \mathrm{~mL})$ was added and the reaction mixture was stirred for $12 \mathrm{~h}$. An aqueous solution of $\mathrm{HCl}$ $1 \mathrm{~N}$ was added (until $\mathrm{pH}$ 1) and the organic phase was washed with water. The combined organic phases were dried $\left(\mathrm{MgSO}_{4}\right)$ and concentrated under reduced pressure. Flash chromatography on silica gel (Cyclohexane/EtOAc/MeOH: 49:49:2) yielded 14 (500 mg, 62 $\%)$ as a gum. $\mathrm{Rf}=0.6$ (DCM/MeOH: 9:1); ${ }^{1} \mathrm{H} \mathrm{NMR}\left(\mathrm{CDCl}_{3}, 400 \mathrm{MHz}\right) \delta(\mathrm{ppm})$ 0.83-0.89 $\left(\mathrm{m}, 21 \mathrm{H}, \mathrm{CH}_{3}\right), 1.00-1.59\left(\mathrm{~m}, 68 \mathrm{H}, \mathrm{CH}_{2}\right), 1.79-1.86\left(6 \mathrm{H}, \mathrm{q}, \mathrm{CH}_{2}-\mathrm{CH}_{2}-\mathrm{O}\right), 1.93-1.99(6 \mathrm{H}, \mathrm{q}$, $\left.\mathrm{CH}_{2}-\mathrm{CH}_{2}-\mathrm{O}\right), 3.40-3.68\left(65 \mathrm{H}, \mathrm{m}, \mathrm{CH}_{2}-\mathrm{O}\right), 3.75-3.78(\mathrm{~m}, 1 \mathrm{H}, \mathrm{CH}-\mathrm{O}), 3.88-3.95\left(4 \mathrm{H}, \mathrm{m}, \mathrm{CH}_{2^{-}}\right.$ 
O), 4.40-4.44 (3H, m, H5), 4.48 (3H, dd, $J=4.1,12.0 \mathrm{~Hz}, \mathrm{H} 6 \mathrm{~b}), 4.69$ (3H, dd, $J=2.1,12.1$ Hz, H6a), 5.09 (3H, d, $J=1.8 \mathrm{~Hz}, \mathrm{H} 1), 5.69(3 \mathrm{H}, \mathrm{dd}, J=1.6,3.4 \mathrm{~Hz}, \mathrm{H} 2), 5.91(3 \mathrm{H}, \mathrm{dd}, J=$ 3.2, 10.3 Hz, H3), $6.11(3 \mathrm{H}, \mathrm{t}, J=10.3 \mathrm{~Hz}, \mathrm{H} 4), 7.24-8.11(60 \mathrm{H}, \mathrm{m}, \mathrm{Har}) ;{ }^{13} \mathrm{C} \mathrm{NMR}\left(\mathrm{CDCl}_{3}\right.$, $100 \mathrm{MHz}) \delta(\mathrm{ppm}) 14.12,19.62,19.68,19.75,22.63,22.69,22.72-29.56,29.65,29.70,29.74$, $29.84,29.91,31.10,31.43,31.63,31.92,32.80,53.03,60.40,62.85,65.53,66.91,67.36$, $67.92,68.61,68.78,68.95,70.15,70.55,80.53,97.64,128.30,128.44,128.57,129.00$, $129.10,129.35,129.73,129.79,129.84,129.88,133.05,133.16,133.43,165.4,165.50$ $166.14,170.69$.

\subsubsection{TriMan-PEG $\mathbf{3 5 0}_{30}$-diether (1).}

Freshly prepared $\mathrm{MeONa}$ solution in $\mathrm{MeOH}(5.3 \mathrm{M}, 48.8 \mu \mathrm{L}, 0.258 \mathrm{mmol})$ was added to a solution of $14(435 \mathrm{mg}, 0.139 \mathrm{mmol})$ in $\mathrm{CH}_{2} \mathrm{Cl}_{2} / \mathrm{MeOH}(100 \mathrm{~mL}, 1: 1)$ and the reaction mixture was stirred overnight. Amberlite IR-120 $\mathrm{H}^{+}$was added and filtered off. The solvent was removed under reduced pressure to furnish $1(255 \mathrm{mg}, 97 \%) .{ }^{1} \mathrm{H} \mathrm{NMR}\left(\mathrm{MeOD} / \mathrm{CDCl}_{3}\right.$ : 70:30, $400 \mathrm{MHz}) \delta(\mathrm{ppm})$ 0.84-0.89 (m, 21H, CH3), 1.04-1.56 (m, 68H, $\left.\mathrm{CH}_{2}\right), 1.79-1.84$ (12H, m, $\left.\mathrm{CH}_{2}-\mathrm{CH}_{2}-\mathrm{O}\right), 3.31-3.88\left(88 \mathrm{H}, \mathrm{m}, \mathrm{CH}_{2}-\mathrm{O}, \mathrm{CH}-\mathrm{O}\right), 4.74(3 \mathrm{H}, \mathrm{s}, \mathrm{H} 1), 7.55$ (2NH, s);

${ }^{13} \mathrm{C} \mathrm{NMR}\left(\mathrm{MeOD} / \mathrm{CDCl}_{3}: 70: 30,100 \mathrm{MHz}\right) \delta(\mathrm{ppm})$ 13.66, 19.26, 19.30, 19.33, 19.37, 19.40, $19.44,22.22,22.31,22.50,24.24,24.31,24.65,25.92,27.83,29.21,29.32,29.39 ; 29.48$, $29.50,29.53,29.64,29.68,29.72,31.27,31.78,32.62,32.64,32.67,36.59,36.65,36.72$, $37.13,37.23,37.25,37.30,37.36,37.39,38.67,38.95,39.25,52.25,61.45,64.22,67.06$, $67.52,67.69,68.41,69.43,69.48,69.53,69.61,70.09,70.11,70.23,70.33,70.35,70.37$, $70.70,71.11,71.15,71.33,71.65,72.56,80.34,80.29,100.08,171.49,173.69 ;$ HRMS calculated for $\mathrm{C}_{194} \mathrm{H}_{182} \mathrm{~N}_{2} \mathrm{O}_{34}[\mathrm{M}+\mathrm{Na}]^{+}$1906.24662, found 1906.2448.

\subsection{Preparation and characterization of Liposomes.}


TriMan-Liposomes were prepared by mixing at $5.4 \mathrm{mM}$ in ethanol the $O, O$-dioleyl- $N-[3 N-(N-$ methylimidazolium iodide)propylene] Phosphoramidate, ${ }^{15}$ the $O, O$-dioleyl- $N$-histamine Phosphoramidate, ${ }^{16}$ the (\{Dioleyloxyphosphoryl)amino $\}$ methyl)-triazolyl $\}$-PEGfluorescein, ${ }^{17}$ and TriMan-Diether in the percentage of $47.25 \%, 47.25 \%, 0.5 \%$ and $5 \%$, respectively. Ethanol solution was then evaporated until formation of a film. The film was hydrated for $12 \mathrm{~h}$ at $4^{\circ} \mathrm{C}$ in $1 \mathrm{~mL}$ of $10 \mathrm{mM}$ HEPES buffer, $\mathrm{pH} 7.4$, vortexed and then the suspension was sonicated for $15 \mathrm{~min}$ at $37 \mathrm{kHz}$ using a Bioblock ultrasonic bath (Bioblock Scientific, Illkirch, France). Liposomes were dialysed (Dialysis Tubing Cellulose membrane; MWCO: $12.4 \mathrm{kDa}$; size: $33 \times 21 \mathrm{~mm}$, Sigma) at $4^{\circ} \mathrm{C}$ for $6 \mathrm{~h}$ and then overnight against 500 mL 10 mM HEPES buffer, $\mathrm{pH}$ 7.4. The lipid concentration was determined with Nile Red. The amount of imidazole in liposomes was determined by the Pauly colorimetric assay. ${ }^{18}$ The amount of TriMan-Diether incorporated in liposomes was determined using the colorimetric resorcinol/sulfuric assay and a standard curve with mannose was used to determine the amount of TriMan-Diether. ${ }^{19}$ The size and the $\zeta$ potential of liposomes were measured by using SZ-100 Analyser (Horiba Scientific, les Ulis, France).

\subsection{Cells and cell culture.}

The murine DC line (DC2.4 cells) was kindly given by Dr P. Jeannin and Dr Yves Delneste (INSERM UMR 892 Nantes-Angers, France). ${ }^{20}$ DC2.4 and HeLa cells (CCL2, ATCC, Rockville MD, USA) were grown at $37^{\circ} \mathrm{C}$ in a humidified atmosphere containing $5 \% \mathrm{CO}_{2}$ in DMEM (DC2.4) or in MEM (HeLa) supplemented with $10 \%$ fetal calf serum (PAA Laboratories, Les Mureaux, France), 100 Units $/ \mathrm{mL}$ of penicillin and $100 \mu \mathrm{g} / \mathrm{mL}$ of streptomycin (Fischer Bioblock, Illkirch, France). 


\section{ACCEPTED MANUSCRIPT}

\subsection{Liposome Binding Assay.}

DC2.4 cells were harvested with trypsin, washed first with complete medium and then with cold phosphate-buffered saline (PBS). Cells $\left(2 \times 10^{5}\right.$ in $\left.0.5 \mathrm{ml}\right)$ in suspension were incubated for $2 \mathrm{~h}$ at $4{ }^{\circ} \mathrm{C}$ with the fluorescent liposomes at the indicated final concentration. For binding inhibition, cells in suspension were pre-incubated for $30 \mathrm{~min}$ at $20^{\circ} \mathrm{C}$ with various mannose concentrations. Then, cells were put on ice and the fluorescent liposomes were added at the indicated final concentration and incubated for $2 \mathrm{~h}$ at $4^{\circ} \mathrm{C}$ still in the presence of mannose, Then, the cells were washed with cold PBS and the cell-associated fluorescence intensity was measured with a flow cytometer (BD LSR, Becton Dickinson; $\lambda \mathrm{ex}=488 \mathrm{~nm} ; \lambda \mathrm{em}=530 / 30$ $\mathrm{nm})$. The fluorescence intensity is expressed as the mean value of the fluorescence intensity (MFI) of 10,000 cells.

\section{Electronic Supporting Information}

NMR data of intermediates and final product relative to the synthesis of TriMan-Diether 1.

\section{Acknowledgements}

We thank David Gosset (P@CYFIC platform at CBM) for his technical assistance in flow cytometry

\section{References}

(1) a) G. B. Patel, G. D. Sprott, Crit. Rev. Biotechnol. 1999, 19, 317-357; b) T. Benvegnu, L. Lemiègre, S. Cammas-Marion, Recent Pat. Drug Deliv. Formul. 2009, 3, 206-220; c) T. Benvegnu, L. Lemiègre, S. Cammas-Marion, Eur. J. Org. Chem. 2008, 4725-4744 ; d) A. Jacquemet, J. Barbeau, L. Lemiègre, T. Benvegnu, Biochimie 2009, 91, 711-717. 
(2) T. Benvegnu, G. Réthoré, M. Brard, W. Richter, D. Plusquellec, Chem. Commun. 2005, 5536-5538.

(3) M. Brard, C. Lainé, G. Réthoré, I. Laurent, C.Neveu, L. Lemiègre, T. Benvegnu, J. Org. Chem. 2007, 72, 8267-8279.

(4) D. M. Whitfield, S. H. YU, C. J. Dicaire, G. D. Sprott, Carbohydr. Res. 2010, 345, 214229.

(5) T. Benvegnu, L. Lemiègre, C. Ballet, Y. Portier, D. Plusquellec in Carbohydrate Chemistry, Chemical and Biological Approaches, Vol. 40 (Eds.: A. Pilar Rauter, T. K. Lindhorst, Y. Queneau), Royal Society of Chemistry, Cambridge, 2014, pp. 341-377.

(6) G. D. Sprott, A. Yeung, C. J. Dicaire, S. H. Yu, D. M. Whitfield, Archaea 2012, 2012, Article ID 513231.

(7) a) L. Matinez-Pomares, J. Leukoc. Biol. 2012; 92:1177-86; b) J. B. Torrelles, A. K. Azad, L. S. Schlesinger, J. Immunol. 2006, 177, 1805-1816; c) H. Tateno, K. Ohnishi, R. Yabe, N. Hayatsu, T. Sato, M. Takeya, H. Narimatsu, J. Hirabayashi., J. Biol. Chem. 2010, 285, 6390-6400; d) S. T. Hollmig, K. Ariizumi, P. D. Cruz Jr., Glycobiology 2009, 19, 568575.

(8) a) N. Jayaraman, K. Maiti and K. Naresh, Chem. Soc. Rev. 2013, 42, 4640-4656; b) V. Faivre and V. Rosilio, Expert Opin. Drug Deliv. 2010, 7, 1031-1048.

(9) a) W. Yeeprae, S. Kawakami, F. Yamashita, M. Hashida, J. Control Release 2006, 114, 193, 201; b) M. Monsigny, A. C. Roche, P. Midoux, Biol. Cell 1984, 51, 187-196; c) J. J. Reina, J. Rojo, Braz. J. Pharm. Sci. 2013, 49, 109-124.

(10) a) S. Espuelas, C. Thumann, B. Heurtault, F. Schuber, B. Frisch, Bioconjug. Chem. 2008, 19, 2385-2393; b) J. M. Benito, M. Gómez-García, C. Ortiz Mellet, I. Baussanne, J. Defaye, J. M. García Fernández, J. Am. Chem. Soc. 2004, 126, 10355-10363; c) J. Rodriguez-Lavado, M. de la Mata, J. Rodríguez-Lavado, M. de la Mata, J. L. JiménezBlanco, M. I. García-Moreno, J. M. Benito, A. Díaz-Quintana, J. A. Sánchez-Alcázar, K. Higaki, E. Nanba, K. Ohno, Y. Suzuki, C. Ortiz Mellet, J. M. García Fernández, Org. Biomol. Chem. 2014, 12, 2289-2301.

(11) K. Bock, J. Arnarp, J. Lönngren, Eur. J. Biochem. 1982, 129, 171-178.

(12) T. K. Lindhorst, M. Dubber, U. Krallmann-Wenzel, S. Ehlers, Eur. J. Org. Chem. 2000, 2000, 2027-2034.

(13)C. Lainé, E. Mornet, L. Lemiègre, T. Montier, S. Cammas-Marion, C. Neveu, N. Carmoy, P. Lehn, T. Benvegnu, Chem. Eur. J. 2008, 14, 8330-8340. 
(14)F. Perche, D. Gosset, M. Mével, M-L. Miramon, J.J. Yaouanc, C. Pichon, T. Benvegnu, P.A. Jaffrès, P. Midoux, J. Drug Targeting 2011, 19, 315-325.

(15) M. Mevel, G. Breuzard, J. J. Yaouanc, J. C. Clement, P. Lehn, C. Pichon, P. A. Jaffres, P. Midoux, ChemBioChem, 2008, 9, 1462-1471.

(16) M. Mevel, C. Neveu, C. Goncalves, J. J. Yaouanc, C. Pichon, P. A. Jaffres, P. Midoux, Chem. Commun. 2008, 3124-3126.

(17) M. Berchel, J. P. Haeaters, H. Couthon-Gourves, L. Deschamps, P. Midoux, P. Lehn, P. A. Jaffres, Eur. J. Org. Chem. 2011, 31, 6294-6303.

(18)L. A. AE. Sluyterman, Biochim. Biophys. Acta 1960, 38, 218-222.

(19) M. Monsigny, C. Petit, A. C. Roche, Anal. Biochem. 1988, 175, 525-530.

(20)Z. Shen, G. Reznikoff, G. Dranoff, K. L. Rock, J. Immunol. 1997, 158, 2723-2730. 
Highlights :

- The synthesis of a trimannosyl archaeal diether-like lipid is described.

- The preparation of liposomes including the glycolipid is proposed.

- Binding of the glycoliposomes to dendritic cells is evaluated. 